\title{
Are Nurses Educated to Educate?
}

\author{
Sheelagh Wickham* \\ Department of Nursing and Human Sciences, University in Dublin, Ireland
}

Submission: April 04, 2017; Published: June 05, 2017

*Corresponding author: Sheelagh Wickham, Department of Nursing and Human Sciences, University in Dublin, Ireland, Tel: 01 -700-5610;

Email: sheelagh.wickham@dcu.ie

\section{Introduction}

The nurse has many roles in their day to day practice. Educator is but one of these. The benefits of patient education have been shown and with the increase in chronic disease the need for patient education is on also growing. While the educator role is recognised as important, there is little preparation for it. Similarly, there is little time, recognition and support for the nurse educator role in everyday practice.

\section{Role of the Nurse as Educator}

The nurse has many roles, including care giver, educator, consultant, research and audit, innovator, patient advocate, leader and administrator to name but a few. The role of educator is a key element in the work of the nurse [1]. The educator role is complex and varied. Though focusing on nurse specialists Hickey et al. [2] broke down the multitude of educational roles needed, dividing them into formal and informal teaching. Hickey's work echoed Scott [3] USA study where she lists the range of people that the specialist nurse is involved in educating - staff nurses, physicians, technicians, healthcare administrators, students, patients and their families. Her study showed that from $24 \%$ to $89 \%$ of the nurses' time was spent in such educational activities. The situation does not appear to have changed in recent years. Healthcare constantly evolves and the availability of new and differing treatments is growing along with patient's expectations. Patient education can help address these every growing and changing requirements.

\section{Preparation for Educator Role}

There is literature on educating nurses and particularly skills education [4]. Similarly, the importance and potential benefits of patient education is well recognised in the literature $[5,6]$. Yet despite this the education of nurses for their education role is rarely explored in the literature and there is no clarity on what preparation is required by the nurse in order to function as educationalists. An interesting study in the UK by Nolan et al. [7] evaluated course curricula and explored nurse preparedness for patient education in rehabilitation. Findings showed that, overall, nurses were ill-prepared for their education role and identified that while the curricula for courses reviewed did include 'explicit references to a nursing role in patient and/or carer education', a lack of standardisation was highlighted. For example, one course for specialist nurses had 92 contact hours in which to achieve 48 learning outcomes, a task that Nolan et al. [7] understandably found hard to envisage. Not surprisingly, they questioned the preparedness of nurses to educate patients.

Undergraduate nursing programme curricula are complex and very busy. The student nurse must learn about the sciences, disease and disease processes and also more abstract concepts such as communication etc. Teaching or education skills is another element which is included in nursing programmes. Yet, as can be imagined, there is limited time to spend on teaching nurses to teach. The situation is little better in postgraduate programmes. At this level the nurse is focused on developing expertise in specific areas and unless the area is nursing education, again there is very limited time to concentrate on education skills and theory, particularly patient education.

It must be a matter of concern where nurse's skills needed to educate the patient, carers etc originate from. Certainly, the lack of obvious training of nurses at any level as educators is worrying, but further work is needed to establish the possible impact this factormight have on patient care and/or patient outcomes.

\section{Benefits of Nurse Educator Role}

Moving into the 21st century, with continuing developments in healthcare, it is important that both patients and healthcare workers keep up to date. The nurse, equipped with expertise and knowledge, is ideally placed to facilitate this. As a recognised professional she nurse is in an ideal position to educate. The nurse has credibility with patients and their families or carers. She also has a depth of knowledge and expertise and access to further research and knowledge. Chronic illness is a growing part of healthcare today. The World Health Organisation states that by chronic diseases, such as heart disease, stroke, cancer, chronic respiratory diseases and diabetes, are the biggest cause 
of mortality, responsible for $60 \%$ of all deaths [8]. Patient education can have a positive impact for patients living with chronic disease [9]. It is important that the role nurses can play in patient education is recognised and planned for, to ensure maximum benefit is derived for the patient. As Sherman [10] identified, nurses benefit from having preparation and structure in their work for patient education.

\section{Where to Now}

Despite the recognition of the benefits the nurse educator role offers there is very limited support for it. Time pressure and poor recognition of the role contribute to this [11]. The benefits of educating patients, for example at discharge are well recognised [12]. Sherman [10] found there was a need for a "a structured approach to effective, efficient patient education".

Moving forward, to ensure patients are supported in recovery and to live as full a life as possible, particularly with chronic disease, patient education must be recognised, developed and supported on an ongoing basis. The nurse educator role must be addressed at a number of levels. Starting in nurse education itself there needs to be an Increase in patient education skills and theory. This increase must be both in recognition and content in undergraduate nursing curricula. It will be important that the student nurse does not just learn about the importance and theory of patient education but also has an opportunity to implement this in practice [13]. Ensuring this happens in a busy undergraduate nursing curricula will be a challenge but an essential and rewarding one. Similarly, patient education should be a compulsory element in post graduate and specialist nursing programmes. Like the undergraduate curriculum, both theory and skills must be included as well as an opportunity to implement patient education in practice.

However, it will not be sufficient to address the patient education role only in the education and training of nurses. The patient education role must also be supported in ongoing practice. This will require recognition of the role of educator by nursing leaders and mangers. Support and on-going education for the nurse to further develop proficiency in the educator role is needed. And perhaps the simplest item, but most difficult to find, time for the nurse to function as a patient educator.

\section{Conclusion}

Nurses are in an ideal situation to provide patient education. Patient education can improve patient's quality of life and patient outcomes. Despite this there is little preparation of the nurse for the role of educator, either in undergraduate training or at post graduate level unless the nurse plans a career in nurse education. While acknowledging the busyness ofcurricula in nurse education at all levels it is essential that preparation for the nurse for their role as educator improves and support and structure is offered for the education role as the nurse progresses through their career.

\section{References}

1. Bergh AL, Karlsson J, Persson E, Friberg F (2012) Registered nurses' perceptions of conditions for patient education - focusing on organisational, environmental and professional cooperation aspects. J Nurs Manag 20(6): 758-770.

2. Hickey J, Ouimette R, Venegone S (2000) Advanced Practice Nursing: Changing roles and clinical applications, $\left(2^{\text {nd }}\right.$ edn), Lippincott, Philadelphia, USA.

3. Scott RA (1999) A description of the roles, activities and skills of clinical nurse specialists in the United States. Clin Nurse Spec 13(4): 183-189.

4. McCormack B, Slater P (2006) An evaluation of the role of the clinical education facilitator. J Clin Nurs 15(2): 135-144.

5. Newcombe T (2016) The importance of the ward nurse's role in patient education following stoma surgery. Journal of Stomal Therapy 36(3): 17-19.

6. Johnson CE, Adle K (2014) The role of the nurse in patient education and follow-up of people receiving oral anti-cancer treatment: an Australian survey. Australian Journal of Cancer Nursing 15(1): 4-12.

7. Nolan J, Nolan M, Booth A (2001) Developing the nurse's role in patient education: Rehabilitation as a case example. Int J Nurs Stud 38(2): 163 173.

8. World Health Organisation (2014) Global status report on non communicable diseases, Geneva, Switzerland.

9. Svege I, Fernandes L, Nordsletten L, Holm I, Risberg M (2016) LongTerm Effect of Exercise Therapy and Patient Education on Impairments and Activity Limitations in People With Hip Osteoarthritis: Secondary Outcome Analysis of a Randomized Clinical Trial. Phys Ther 96(6): 818-827.

10. Sherman, Jessica R (2016) An Initiative to Improve Patient Education by Clinical Nurses. MEDSURG Nursing 25(5): 297-333.

11. Bergh A, Friberg F, Persson E, Dahlborg-Lyckhage E (2015) Perpetuating 'New Public Management' at the expense of nurses' patient education: a discourse analysis. Nursing Inquiry 22(3): 190-201.

12. London F (2016) No time to teach: The essence of patient and family education for health care providers. ( $\left.2^{\text {nd }} e d n\right)$, Atlanta Prictchett \& Hull Associates, USA.

13. DeLano A (2017) Nurses as Educators. Preoperative Education Reducing Patient Anxiety in Robotic Prostatectomy: A Patient's Experience. MEDSURG Nursing 26(1): 62-63. 
This work is licensed under Creative Commons Attribution 4.0 License
Your next submission with Juniper Publishers will reach you the below assets

- Quality Editorial service

- Swift Peer Review

- Reprints availability

- E-prints Service

- Manuscript Podcast for convenient understanding

- Global attainment for your research

- Manuscript accessibility in different formats

( Pdf, E-pub, Full Text, Audio)

- Unceasing customer service

Track the below URL for one-step submission https://juniperpublishers.com/online-submission.php 